\title{
Volume 51: O Início de um Novo Ciclo
}

$\mathrm{E}$ STAMOS NO INÍ́CIO de 2007. São passados, portanto, mais de 55 anos $\checkmark$ desde o lançamento, pela Sociedade Brasileira de Endocrinologia e Metabologia, dos Arquivos Brasileiros de Endocrinologia, em setembro de 1951, na cidade do Rio de Janeiro. No entanto, descontados os 5 anos da interrupção forçada de sua publicação, apenas há pouco fechamos o ciclo dos 50 !

A partir desse volume 51 iniciamos agora um novo ciclo da revista, com cara nova, sobriedade profissional, qualidade científica plena e o crescente talento de nossos autores.

A marca " 51 " nos remete de imediato a uma imagem de marketing, a da "boa idéia". Mas que ela se associe, nesse momento, à embriaguez e ao embevecimento de seu conteúdo científico, da beleza de sua apresentação e do cuidado com os detalhes.

Uma Sociedade que avança sistematicamente na busca de seu aprimoramento profissional, alicerça-se e cresce sobre a base de conhecimento que consegue produzir e divulgar. Para tanto, conta com a pujança de seus cada vez mais freqüentes e concorridos eventos, mas, principalmente, com a disponibilidade, a qualidade e a pontualidade de sua revista científica.

Assim, para comemorar os 50 volumes dos ABE\&M, publicados desde 1951 até 2006, e celebrar o início de um novo período, apresentamos nessa edição de Fevereiro de 2007 (volume 51, número 1) uma nova concepção gráfica, reformulada em sua aparência, formatação e paginação, buscando um visual mais moderno, prático e atraente para nossos leitores.

O estudo foi encomendado e concebido pela Arquiteta Vera Suplicy, responsável, também, pelo projeto anterior da revista, implementado em 1998. Em suas próprias palavras: "Nesta última década a revista Endocrinologia \& Metabologia (ABE\&M) sofreu algumas mudanças e contabilizou diversas conquistas: mudou o design, aumentou o número de edições anuais, foi indexada no PubMed / Medline (Index Medicus), seus artigos figuram nos mais importantes Bancos de Dados Médicos (Medline, SciELO, IMLA, LILACS) e uma versão eletrônica de textos completos está disponível no SciELO.

Passados 10 anos, a evolução continua com o novo visual da revista. Nossa meta foi, mais uma vez, facilitar a leitura, aumentar a clareza e tornála mais leve e agradável para a leitura. O logotipo foi atualizado e a capa reformulada. Algumas fontes de letras foram substituídas para maior legibilidade. O primeiro caderno continua impresso em 4 cores e os restantes agora o serão em duas cores (preto e vermelho). Também modificamos o visual das tabelas e passamos a contar com a segunda cor (e suas gradações) nos gráficos. Esperamos que gostem e que nos enviem sugestões".

Quero enfatizar que essas modificações na aparência, belas por si só, servirão principalmente para emoldurar um objetivo maior: o do aumento da periodicidade. Nossos ABE\&M, que foram editados trimestralmente (4 edições/ano) até 1998 e passaram a sê-lo bimestralmente (6 edições/ano) até ao ano passado, agora o serão por meio de nove edições anuais. Dessas, seis serão edições regulares (nos meses pares) e três, edições especiais temáti- editorial

Claudio E. Kater

Professor Associado de Medicina, Disciplina de Endocrinologia, Departamento de Medicina, Universidade Federal de São Paulo, SP.

Editor-Chefe, ABE\&M 
cas. Neste ano de 2007 teremos em Março: "Diabetes Mellitus e Doença Cardiovascular", com os Drs. Beatriz D. Schaan e André F. Reis como editores-convidados, em Julho: "Carcinoma de Tireóide", com os Drs. Edna T. Kimura, Laura S. Ward e James Fagin, como editores convidados e em Novembro: "Síndrome de Cushing", com os Drs. Lucio Vilar, John Newell-Price e eu próprio, como convidados.

Algumas novidades, como os editoriais sobre um mesmo assunto, mas analisado e discutido por especialistas de área distintas, estão acontecendo agora. Outras aguardam seu momento para implementação: o tão esperado processamento online de manuscritos, que ainda aguarda um software a ser disponibilizado pela equipe SciELO, poderá acontecer até o meio do ano resolução do material necessário. A disponibilização online de textos completos em inglês, visando atingir um público internacional e aumentar a possibilidade de citação de nossos artigos e elevar os futuros índices de impacto, também poderá ocorrer ainda esse ano, na medida em que haja um orçamento disponível para tal. Em termos de indexação internacional, completaremos com esse número nossa aplicação para o almejado ISI-Thomson Scientific, com a possibilidade de passarmos a figurar em mais um banco de dados internacional da mais alta relevância.
Nosso escritório editorial aumentou de tamanho e conta agora com mais espaço para trabalho e para a guarda de material. Convidamos todos a visitálo, quando possível.

Por fim, é hora de despedir-me de todos nesse término de gestão e de passar o bastão. Foram 12 anos seguidos trabalhando dedicadamente pela qualificação da nossa revista, um trabalho árduo, longo e cansativo, mas sempre prazeroso. Tenho muito orgulho do que pude fazer e dos muitos e importantes amigos que conquistei, entre colegas, colaboradores e leitores. Sinto-me honrado e agradecido pelo que tive de colaboração, estímulo, amizade e compreensão.

Os problemas e dificuldades que estiveram presentes algumas vezes foram sempre pequenos perto das vitórias e conquistas. No seu devido tempo a Sociedade poderá saná-los e saberá reconhecer as justas causas e reivindicações.

Gostaria de poder agradecer individualmente a todos os que me foram caros, sinceros e dignos - cada uma à sua maneira -, nesses 12 anos de convivência. Contudo, premido pelo espaço e impossibilitado de lembrar de todos os nomes, faço um agradecimento geral e deixo um abraço cordial a cada um com quem tive a satisfação de interagir. 